\title{
Two Mediaeval Manuscripts on the Worship of the Stars from the Fujii Eikan Collection
}

\section{Ikuyo Matsumoto}

\begin{abstract}
A large number of mediaeval documents addressing specific liturgies directed to stars and planets and their iconographical and ritual representation have been preserved in Japanese private and public collections. The Fujii Eikan Archives, kept at the Art Research Centre of Ritsumeikan University, Kyoto, comprises five manuscripts related to the worship of stars, including some hitherto unpublished material. They are essential texts for the study of starrelated rituals and the nature of stars in the early medieval period. This article offers an analysis and translation of two of these texts, which represent different genres of ritual manuals devoted to celestial bodies. The first text consists of the liturgical prescriptions for a ritual dedicated to the Personal Star; the second outlines divinatory practices associated with the Nine Luminaries.
\end{abstract}

\section{Introduction}

The Fujii Eikan Collection holds over 420 items of antiquarian objects and manuscripts. The collection was the result of a lifelong activity of Takaaki Fujii (1913-83), and it is now kept at the Art Research Centre of Ritsumeikan University, Kyoto. It includes five manuscripts from the early medieval period, which are related to the worship of stars:

1. Sukuyō giki 宿曜儀軌 (Ritual Manual of Astrology). This is a copy of a section of the Shingon giki kept at the Tō-ji, Kyoto. Copied by the monk Shinson 親尊 and dated 1257 (Kamakura 鎌倉 period).

2. Tōnenshō-ku sahō shidai 当年星供作法次第 (Ritual Procedures of the Worship of Personal Stars). This is a copy of a section from the Shingon giki kept at the Saidai-ji, Nara. Copied by the monk Eison 叡尊and dated 1279.

3. Hokuto-ku ho 北斗供法 (Ritual of the Polar Star). Transmitted by a monk of the Jūmujin-in temple affiliated to Kōzan-ji, Kyoto, and dated 1278 .

Ikuyo Matsumoto, 'Two Mediaeval Manuscripts on the Worship of the Stars from the Fujii Eikan Collection', Culture and Cosmos, Vol. 10 no 1 and 2, Autumn/Winter and Spring/Summer 2006, pp. 125-144.

www.CultureAndCosmos.com 
126 Two Mediaeval Manuscripts on the Worship of the Stars from the Fujii Eikan Collection

4. Seishuku jiingyō keimyōshū 星宿字印形契明集 (Anthology of the seed-syllables, mudras, and mantras of the Constellations). Copied by Sen'e 宣恵 and dated 1279.

5. Kuyō hireki 九曜秘暦 (The Secret Calendar of the Nine Luminaries). This is a manuscript from the late Heian period, as discussed in some detail below.

These five manuscripts were not collected systematically, but they all have colophons that clearly indicate the temples and lineages within which they were transmitted. They include some hitherto unpublished material, which provides essential texts for the study of star-related rituals and the nature of stars in the early medieval period. In this article, I would like to present two texts: the first consists of the liturgical prescriptions for a particular star ritual; the second outlines divinatory practices associated with the Nine Luminaries.

\section{Tōnenshō-ku sahō shidai (Ritual Procedures for the worship of the Personal Stars)}

The ritual for one's Personal Star is also known as zokushō-ku 属星供, or hoshi-ku 星供. It aims to prevent misfortune and invite good fortune by chanting the mantra of one's Personal Star (zokushō or honmyōshō 本命星), which is determined by the Zodiac sign of one's year of birth.

In Japan the stars were thought to exert great influence on the lives and fortunes of everybody, and rituals to them were often performed. The origin of the Personal Stars' rituals may be traced to the belief in the Personal Day (honmyōbi 本命日), which was upheld by Yin-Yang (Onmyōdō) practitioners, and was concerned with the allotment of fortune in a specific day. The Personal Day was determined by a combination of the twelve Zodiac signs and the birth year, and people were expected to act discreetly and carefully on that day. The belief in the Personal Star, on the other hand, was concerned with a person's fortunes in each year. In the ritual devoted to this Star, each year was associated with one of the Nine Luminaries (the Sun; the Moon; the five major planets, Mars, Mercury, Jupiter, Venus and Saturn; the star held responsible for eclipses, Ragō; and the comet, Keitō), each signifying good and bad fortunes. From the tenth century onwards, the belief in the stars of the Big Dipper became widespread, especially in aristocratic circles; as a consequence, the Personal Stars of the homonymous ritual started to be more often allocated to the seven stars of the Big Dipper ( $\mathrm{J}$.

Culture and Cosmos 
hokuto shichisei), and the ritual was absorbed into the ritual of the Big Dipper (J. hokuto-ku).

Below is an integral translation of the ritual manual for the worship of the Personal Star, which is in the Fujii Eikan collection. I have edited the text of the Japanese manuscript, adding the punctuation. Characters that are illegible due to worm damage are indicated by empty square brackets. The English translation, by Meri Arichi and Lucia Dolce, has been amended in places to make the meaning easier to understand.

\section{Ritual Procedures for the worship of Personal Stars}

Enter the Hall and bow in front of the altar.

Next, seat and bow

Next, [apply] unguents (zuikō 塗香)

And purify [your] three mysteries [body, mouth and mind]

Next, protect the [deities of the] three divisions [of the mandala] with your armor;

Next, purify the holy water and the offerings;

Purify the land by visualizing the seed-letter A.

Next, visualize the Buddha, invaluable and excellent as a diamond.

Next, pay your earnest respects to the main deity.

[

Next, [perform] the five repentances.

Next, [ ]

Next, [recite] the esoteric precepts (sanmaya kai 三昧耶戒).

Next, raise your prayers to the assembly of the main deity, the Star of the Year, the Seven Stars of the Big Dipper and the various stars and constellations.

Next, [recite] the Five Great [Bodhisattva] Vows.

Next, make the universal offerings to the three powers [that is, the power of sentient beings, the power of the dharma and the power of selfachieved merits].

Next, the Great Vajra Wheel.

Next, form the mudra of the Earth and then form the mudra of the Four Directions.

Next, the contemplation of the ritual place (dōjōkan 道場観):

Form the Tathagata's fist mudra

And visualize the Seed-letter A, which is placed on the altar. 
128 Two Mediaeval Manuscripts on the Worship of the Stars from the Fujii Eikan Collection

The Seed syllable transforms itself into a palace tower bedecked with seven treasures. Inside there is an exquisite altar, on top of which is again a letter A, which changes into a lotus pedestal, on which another seedletter A appears, which then turns into a star-shaped [object]. This, in turn, is transformed and becomes the sun and the stars, encompassing each other. The seven stars of the Big Dipper and the other constellations [appear] in front and in the back, surrounding the altar.

Next purify the seven parts of your body (left and right shoulders, abdomen, heart, forehead, throat, and crown)

[ ]

[Visualize a space as] big [as that represented by] the Bodhisattva Kokuzō

[Visualize a space as] small as the Vajra Wheel

Next, dispatch the carriage and invite the main deity to descend Invite the great deities who are the key [for the elimination of evil]

Recite the four mantras and join the palms

Next, construct the sacred boundary [reciting the mantra of its guardian,] Batō Kannon

Expel the demons by spreading a net in the space and by fire

Next, the great sanmaya assembly

Offer holy water

Place the lotus pedestal

(After finishing these preparations) Make a fist with the right hand and rest it on the hip, and turn the back of the left hand with the five fingers up

Place the fist on the shoulder, and chant the following mantra Namah samanta-buddhānām ah 襄莫三満多没駄南悪

(Praise to all the Buddhas who pervade everywhere)

Next, light the candles

Form the mudra and recite the mantra of the five offerings

Perform a prayer dedicated to all [beings]

Offer incense, seasonal flowers, burned incense, tea, food, sweets and candles

[Recite] the praise to the fourfold wisdom [of the Tathagatas]

[Make] the universal offerings to the three powers

Culture and Cosmos 
Next, pay homage to the buddhas (raibutsu 礼仏):

Praise to the Buddha Vairocana

Praise to the Bodhisattva Shisetchi 四摂知 [who encompasses all the virtues of Vairocana]

Praise to the Star of the year, the Personal Star and the sun and stars

Praise to the Big Dipper and the other Constellations

Praise to all the Buddhas and Bodhisattvas of the Diamond World

Praise to all the Buddhas and Bodhisattvas of the Womb World

Next, identify with the main deity, Myōken, the Polar Star, and invite it thousand times.

Recite the mantra of the Big Dipper

the mantra of the Seven Luminaries

and the mantras of Twenty-eight Lunar Mansions.

[Recite the mantras of] the Star of the year and of the Sun and stars;

of the Personal Star, the Personal Day, the Personal Zodiac, and the Personal Constellation;

of Butsugen, the adamantine auspicious (Kongō kisshō 金剛吉祥).

Disclose the movement of the various stars

Invoke the god Yama,

the Great Vajra Wheel

and Ichiji kinrin.

Offering of verses on the Buddhist truth (hosse 法施)

[Recite] the Heart Sutra

The verses on the eight negations (八不偈頌 happu geju) say:

Neither arising nor ceasing

Neither eternal nor impermanent

Neither one nor many

Neither coming nor going

The verses of the dependent origination (hosshinge 法身偈, lit. the dharma-body) say:

All dharmas arise from causation

These dharmas cease because of causation.

The Tathagata expounds this [law of] causality

This is the explanation of the Great Srāvaka.

Next, [tie] the five mudras of the offerings and [recite] the [correspondent] mantras 
130 Two Mediaeval Manuscripts on the Worship of the Stars from the Fujii Eikan Collection

Next, perform a prayer dedicated to all [beings]

Next, make the offerings (jiku 事供):

[offer] holy water

[offer] silver coins, notes and banner

praise the fourfold wisdom

[make] the universal offerings to the three powers and the rest

Next, pay homage to the buddhas (raibutsu)

Next, the transference of merit

Next, the five repentance, and you should recite the fifth of them turning to the eyes of the Buddha

Next, dissolve the sacred boundary

Protect [the venerables of] the three sections [of the mandala] with your armor;

And bow to all.

Next burn the silver, money, banners and the other offerings

Call the helpers and make them burn these

While the Ajari recites the verses and the Heart Sutra.

Next, bow to all in front of the altar

and exit the Hall.

2. The Secret Calendar of the Nine Luminaries (Kuȳ hireki 九曜秘暦)

Kuyō (Ch. Jiuyao), the Nine luminaries, is the collective name given in Chinese sources to seven celestial bodies and two planetoids: the Sun, the Moon, the five major planets (Mars, Mercury, Jupiter, Venus and Saturn), Ragō (Sk. Rāhu), which was held responsible for eclipses, and the comet Keitō (Sk. Ketu). ${ }^{1}$ These celestial bodies were often represented by anthropomorphic figures, and occasionally by animals. Each was regarded as possessing benevolent and malevolent characteristics, and they were believed to control human destiny. They are portrayed in the Buddhist text known as the Kuyo hireki (The Secret Calendar of the Nine Luminaries).

The manuscript introduced here was previously possessed by the Jisonin, a subtemple of the major Shingon temple Kajūji. Four additional manuscripts of the Kuyo hireki are known to exist: the first, formerly of the Kanchi-in at Tōji, is in the Spencer Collection of the New York Public Library; the second, copied by Seigen 成賢 and dated Jōō 3, 1224, is in the collection of the Boston Museum of Fine Arts; the third, copied by

1 Editor's note. Ketu is normally the Moon's south node.

Culture and Cosmos 
Sōkan 宗観 in Tenji 2, 1125, was in the Yoshimizu archive of Shōren-in and is now possessed by the New York Metropolitan Museum; and the fourth is a manuscript copied by Keibō 敬宝 and held at Tōji. Scholars are divided on the question of the original creation of the Kuyo hireki: one theory posits that it was created in Tang China and the other argues for a Japanese origin.

The manuscript of the Kuyo hireki from the Fujii Eikan Collection is in the format of a small booklet, measuring $21.8 \mathrm{~cm}$ in height $\mathrm{x} 16.5 \mathrm{~cm}$ in width. According to the colophon, this manuscript was copied in Heiji 1, 1159, by Kōzen 興然, a monk of the Jison-in tradition of the Kajū-ji temple. The colophon demonstrates that the manuscript had been transmitted within the Jison-in tradition of Kajū-ji in the Ono lineage, one of the two main lineages of Shingon Buddhism. A printed edition of this work, apparently based on this manuscript, appears in the seventh volume of the portion of the Taishō Shinsh $\bar{u}$ Daizōkyō that is devoted to Buddhist

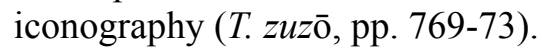

The images and brief descriptions of each of the Nine Luminaries in the Fujii Eikan manuscript are reproduced below. The photographic images differ from those in the printed edition in the Taishō canon, which are not as detailed. It should be noted that the last two images, those of Rāhu and Ketu, have been excised from the manuscript at some time in the past and mounted as hanging scrolls. They have been reproduced here from the scrolls in the Fujii Eikan Collection. Perhaps because they were excised from the text, the only information about these two celestial bodies that remains is their mantras.

The manuscript begins with a statement proclaiming the difficulty of pursuing the meaning of the heavens and the doctrines of the laws of the heavens, and continues by asserting that the text has been compiled and collated after a search of various scriptures. The prefatory statement goes on to note that the title Kuyo hireki has been given to the textual material, and to request the reader to peruse it carefully.

Next, the manuscript gives a mantra for avoiding calamity, the dharani of the great White-Robed Avalokiteśvara (Jp, Byakue Kannon), in Chinese characters. The text states that if this mantra is recited and the correspondent mudra is formed, a mountain of evil acts accumulated over time will all be erased, everything will go well, and all will be completed successfully without exception. Furthermore, if a practitioner experiences doubts during spiritual training and wants to know whether the future will go smoothly, the following actions should be taken. After covering one's head with a cloth, one should rub it circularly with the right hand and 
132 Two Mediaeval Manuscripts on the Worship of the Stars from the Fujii Eikan Collection

recite the mantra of the White-Robed Avalokiteśvara twenty-one times while reclining on one's right side and envisioning the form of the WhiteRobed Avalokiteśvara, without thinking of extraneous matters. If this is done, one may see an emaciated old man with a bearded chin, or the pure acts of the monarch, or a young woman clad in a white gown, or flowers and fruit in one's dreams and these are all auspicious and excellent signs. In contrast, seeing a Buddha wearing filthy and torn garments or an ugly woman is inauspicious sign, meaning that there will be difficulties and matters will not go smoothly. The text also explains that if the fortune derived from a person's sun, month or the five stars is bad, there will be conflict and a loss of calm. However, if one builds a site devoted to the practices for Avalokiteśvara and prays to avoid great calamity by reciting the dhärani of the White-Robed Avalokiteśvara continually, the bad fortune caused by the luminaries and other celestial bodies will be extinguished, and it will be transformed into good fortune. The manuscript thus emphasizes that the bad fortune caused by the operations of the Nine Luminaries can be completely erased by the recitation of a mantra, and once more it records the dhārani of Avalokiteśvara, this time in Sanskrit, followed by the dharrani of the Big Dipper. It then goes on to explicate the good and bad fortune associated with each luminary.

This spectacular manuscript evokes a distant Central Asian world, as the name of each of the Nine Luminaries is given in the languages of three Asian peoples, transcribed in Chinese characters: Sogdian, Persian, and Indian (Sanskrit). After the mantra of each luminary, an image of the luminary is included, followed by an explanation of the fate of those born on the day governed by the luminary.

Luminary of the Sun, The Vast Yang (Nichiyō Taiyō 日曜太陽)

Sogdian name: Myr (Mitsu 密) ${ }^{2}$

Persian name: $\bar{E} w$ šambhih (Yōshinmochi 曜森勿)

Indian name: Āditya（Aniteiya 阿你底耶）

The Luminary of the Sun is depicted here in the form of a woman with a flaming sun in her left hand and the stem of a lotus flower held in her

2 Editor's note. The Sogdian and Persian names of the seven luminaries have been added following the table included in Yano M., "The Hsiu-yao ching and its Sanskrit Sources," in Swarup, Bag and Shukla, eds. History of Oriental Astronomy, p. 131. The Sino-Japanese characters, which are phonetic transcriptions of the original names, are included as they appear in the Fujii Eikan manuscript, but variants appear in other manuscripts.

Culture and Cosmos 
right hand. Her headdress features the head of a dragon flanked by that of a horse and a bird (Fig. 1). According to the Rig Veda, the classic of Indian mythology, the deified sun travels across the sky in a chariot drawn by seven horses. Its blazing heat and shining light bring prosperity to people in the form of the dawn that dispels darkness.

The text says: Those who have new personal ornaments, embroideries of gold and silver and weddings, and so on will have good fortune. Bad fortune will be had in thievery among companions, meeting with illness, and so on. Men and women born on this day will have forty days of misfortune. They will not be at a loss for money and will be favored by the monarch and obedient to their parents. They will display leadership in their families and will flourish in accordance with their stations in life, but the spans of their lives will be short. When they fall ill, they will straddle the border between life and death but will survive.

When the fifth day of the fifth month falls on the day of the Luminary of the Sun, all matters will mature fruitfully and there will be balance between fair and rainy days during the year. In the case of an eclipse of the sun or moon or an earthquake, it will be very cold. If a commander encounters an enemy encampment, he should not strike first into the camp of the foe. A commander should wear a white robe, ride a white horse, tie his armor with white bindings, and hoist a white banner.

The Luminary of the Moon, the Vast Yin (Getsuyō Taiin 月曜太陰)

Sogdian name: M’x (Baku 莫)

Persian name: Dō šambhih (Rugamochi 婁禍森勿)

Indian name: Soma (Soma 蘓摩)

The Luminary of the Moon is depicted here in the form of a woman with the flaming sphere of the moon in her right hand and a blooming lotus flower held in her left. She wears a headdress that features the figures of a dragon (Fig. 2). The Indian name refers to the intoxicant soma that was drunk in religious rituals, and whose drops were likened to moonlight. The light of the moon was said to produce a cooling radiance that would cause one to forget oppressive heat. This was a metaphor for the compassion of the Buddha, which cools the heat of worldly passions.

The text says: There is good fortune in seeking rank and offices, in performing good works, in not taking a wife or concubine, and so on. There is bad fortune in taking medicine, assembling a suit of armor, passing a belt through one's clothing, wearing new clothes, telling false tales, and so on. Men and women born on this day will have ninety days 
134 Two Mediaeval Manuscripts on the Worship of the Stars from the Fujii Eikan Collection

of misfortune. In the daylight hours they will be gentle and mild, while at night they will be vigorous. Their character will display filial piety, and they will be polite, intelligent and clever in conversation. As they are full of affection, they are esteemed and respected by everyone. However, they are enamored of glory and intrigue, but will never have trouble in affairs of the heart. Men will have many wives, and women will be satisfied with the love of their husbands.

If the fifth day of the fifth month falls on the day of the Luminary of the Moon, there will be much illness in that year. If an eclipse of the sun or moon or an earthquake should occur, many will perish from illness. If a commander encounters an enemy encampment, he should wear green robes, ride a swift stead, tie his armor in green bindings and unfurl a [green] banner.

Luminary of Fire, Mars, Flickering Star (Kayō keikoku 火曜竾惑)

Sogdian name: Wnx'n (Sekkan 雪漢)

Persian name: Šě šambhih (Seishimochi 勢森勿)

Indian name: Anggāraka (Fungaraka 粪哦羅迦)

The Luminary of Fire, Mars, is depicted as a man with four arms. In his right hands he holds an arrow and a halberd and in the left hands a bow and a sword. His headgear is in the shape of a donkey (Fig. 3).

The text says: There is good fortune in competition, defeating enemies, storing treasures, and so on. There is bad fortune in marriage, illness, and so on. Men and women born on this day are intelligent, display filial piety, take pleasure in riding horses and are intensely jealous, but their spirits burn with righteousness.

If the fifth day of the fifth month falls on this day, the year will be one of war and violent disturbances, and many soldiers, civilians, and livestock will be lost. If an eclipse of the sun or moon or an earthquake occurs, there will be great damage. If a commander encounters an enemy encampment, he should wear red robes, ride a red horse, tie his armor in red bindings, and hoist a crimson banner.

Luminary of Water, Mercury (Suiyō Shinsei 水曜辰星)

Sogdian name: Tyr (Shō 商)

Persian name: Čahār šambhih (Seishinmochi 掣森勿)

Indian name: Budha (Buda 部陀)

The Luminary of Water, Mercury, is depicted in the form of woman with a writing brush in her right hand and a paper in her left. She wears a

Culture and Cosmos 
headdress in the shape of a monkey (Fig. 4). In the Rig Veda, Mercury is considered the deity of the Law and the stars, who governs the movement and order of the heavens. She is also associated with the sacred water in the heavenly realm.

The text says: There is good fortune in marriage, writing letters, washing one's hair, divining one's fortune, and so on. There is bad fortune in removing mourning clothes, taking pleasures, and so on. Someone born on this day will use eloquent language and will be of brilliant character. Their facial features will shine with joy. Their figure will be upright and sterling. They are fond of music and medicine and excel in learning.

When the fifth day of the fifth month falls on the day of the Luminary of Water, the rivers will overflow their banks, and heat will be insufficient for all and cold will likely prevail. If an eclipse of the sun or the moon or an earthquake were to occur on this day, there will be conflicts on the borders. If a commander encounters an enemy encampment, he should wear emerald green robes, tie his armor in emerald green bindings, and hoist a green banner.

\section{The Luminary of Wood, Jupiter (Mokuyō saisei 木曜歳星) \\ Sogdian name: Wrmzt (Kotsusōshi 鶻勿斯) \\ Persia name: Panĵ šambhih (Honshinmochi 本森勿) \\ India name: Bŗhaspati (Burikababatei 勿哩訶婆跛底)}

The Luminary of Wood, Jupiter, is depicted in the form of a man holding a flower container in his left hand and wearing a headdress in the shape of a boar (Fig. 5).

The text says: There is good fortune in appointments to official posts and ranks, audiences with the monarch, obtaining a good spouse, in medicines and plants, and in planting fruits, purchasing a new residence, taking medicine and bathing, and so on. There is bad fortune in accepting donations, in conflicts, in being cunning, and so on. Those born on this day will be blessed with wealth and honors and be admired by all. They are genuine, decisive and firm. They will be favored by princes and are in a position to be given the responsibility of the state. They employ eloquent language; their cultivation shines and they are sociable. They are obedient to their parents and superiors.

If the fifth day of the fifth month falls on this day, noble people will meet with many calamities. If a commander encounters an enemy encampment, he should wear a yellow robe, ride a horse with a red main speckled with white and a yellow tail, tie his armor with yellow 
136 Two Mediaeval Manuscripts on the Worship of the Stars from the Fujii Eikan Collection

bindings, and hoist a yellow flag.

The Luminary of Gold, Venus (Kinyō Taihaku 金曜大白)

Sogdian name: N’xy $\delta$ (Nakin 那歇)

Persian name: Šaš šambhih (Sōshinsō 數森勿)

Indian name: Śukra (Seikara 成羯羅)

The Luminary of Gold, Venus, is depicted as a woman wearing a headdress in the shape of a cock. She stands, holding a biwa in both hands (Fig. 6).

The text says: There is good fortune in completing clerical tasks swiftly, acting virtuously, becoming a teacher, learning techniques and arts, renewing clothing, marriage, and so on. There is bad fortune in behaving with stealth or cunningly, and so on. People born on this day are very intelligent, blessed with wisdom, and they will bring about much happiness and prosperity. They will long be admired as teachers. They are obedient to their parents and loved by their siblings.

If the fifth day of the fifth month falls on the day of the Luminary of Gold, many stored provisions will be lost, and brigands in all directions will be vanquished and die. If an eclipse of the sun or moon occurs on this day, there will bad winds, thunder, and rain that will cause some damage to the seedlings in the fields. If there is an earthquake, the monarch and marquises will fall into conflict. If a commander encounters an enemy encampment, he should wear white robes, ride a horse with red main speckled with white and a yellow tail, tie his armor with yellow bindings, and hoist a yellow banner.

\section{The Luminary of Earth, Saturn (Doyō chinsei 土曜鎮星)}

Sogdian name: Kyw’n (Shisō 枳淙)

Persian name: Haft šambhih (Kyūshinmochimoku 拿森勿木)

Indian name: Śanaiśucara (Shanoisekira 捨乃以析羅)

The Luminary of Earth, Saturn, is depicted as an old man, naked from waist up, and wearing a long trailing garment. He stands holding a staff with his right hand, while in his left hand he holds an incense burner (Fig. 7).

The text says: There is good fortune in promotions in rank, appointments and attaining posts, striking first, amassing property, following precepts, and so on. There is bad fortune in prevaricating, committing fraud, and so on. Those born on this day are fond of books and theorizing. They are gallantly decisive and firm. They are intelligent,

Culture and Cosmos 
submissive to others, but have short life-spans. There is bad fortune in prevaricating and trickery.

If the fifth day of the fifth month falls on day of the Luminary of Earth, many diseases will occur that year, but carrying gold and silver on one's person will bring good fortune. If an eclipse of the sun or moon or an earthquake occurs on this day, there will be a failure of crops in the fields. If a commander encounters an enemy encampment, he should wear garments of plain cotton, ride a horse or a bird trailing cotton, and unfurl cotton bindings and a cotton banner.

\section{$R \bar{a} h u$ (Ragō 羅睺)}

Rāhu is depicted as having three faces and four arms. Cloth is wrapped around its body. It sits atop a prone water buffalo. It holds up the sun and moon, and grasps a dagger and a human being with its other hands (Fig. 8). According to the myth contained in the Rig Veda, Rāhu was spotted by the sun and the moon while tasting the amrita of immortality, and his head was cut off by Vishnu. His head was said to have become the star Rāhu. Rāhu thereafter held a grudge against the sun and the moon, and in revenge causes solar and lunar eclipses. In the Shichiyō jōsai ketsu (Secret decisions on removing misfortune caused by the seven stars) it is explained that this star usually hides its course and cannot be seen, but it casts its shadow over the moon, causing an eclipse.

\section{Ketu (Keitō 計都)}

Keitō is depicted as having three faces and six arms. Serpents coil around its limbs, and it sits on the back of a prone dragon. He holds up the sun and moon, grasps a halberd with two hands, and grips an imaginary birdlike creature with the face of a monkey and a human form in its other hands (Fig. 9). According to Indian mythology, while the head of the demon Rāhu, cut off by Vishnu, became the star Rāhu, his body became the comet Ketu. Again, the Shichiyō jōsai ketsu explains that this star can cause bad luck for human beings. The body of the Kuyo hireki, however, does not detail the good or bad fortune caused by these two stars. 
138 Two Mediaeval Manuscripts on the Worship of the Stars from the Fujii Eikan Collection

Tōnenshō-ku sahō shidai 当年星供作法次第 (Ritual Procedures of the Worship of Personal Stars), original manuscript, Fujii Eikan Archives, Art Research Centre, Ritsumeikan University, Kyoto.
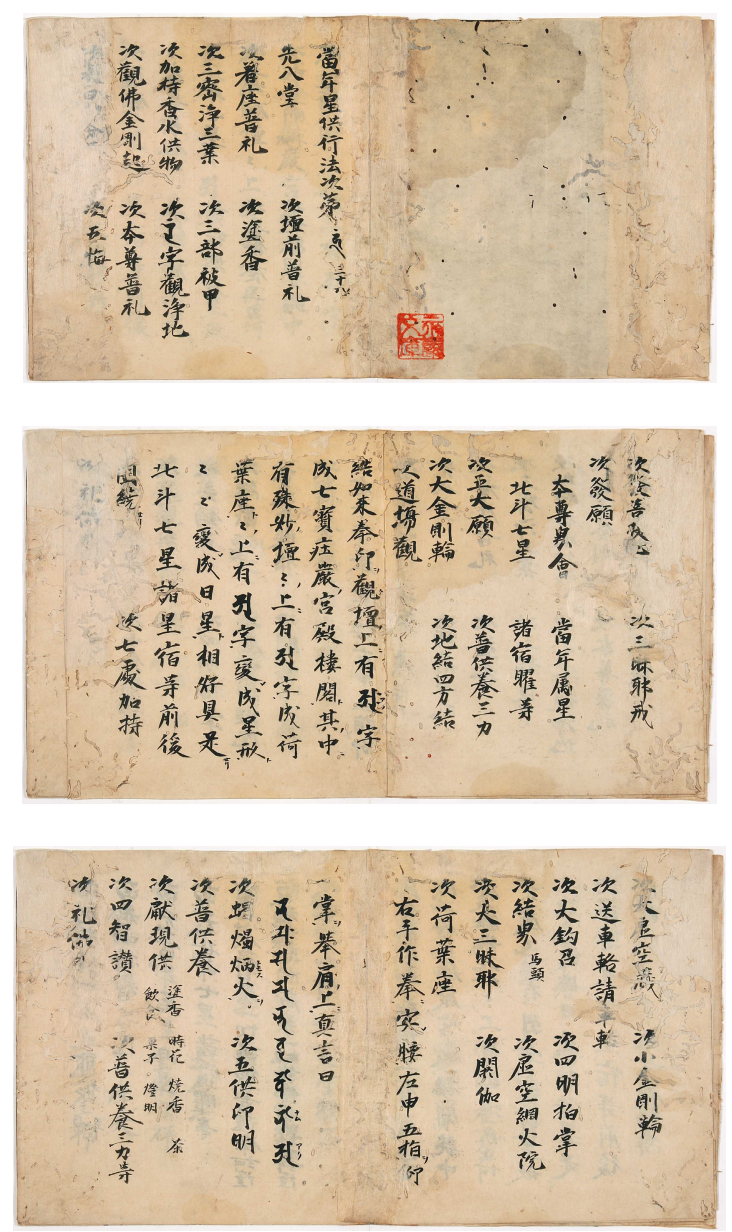

Culture and Cosmos 
Ikuyo Matsumoto 139
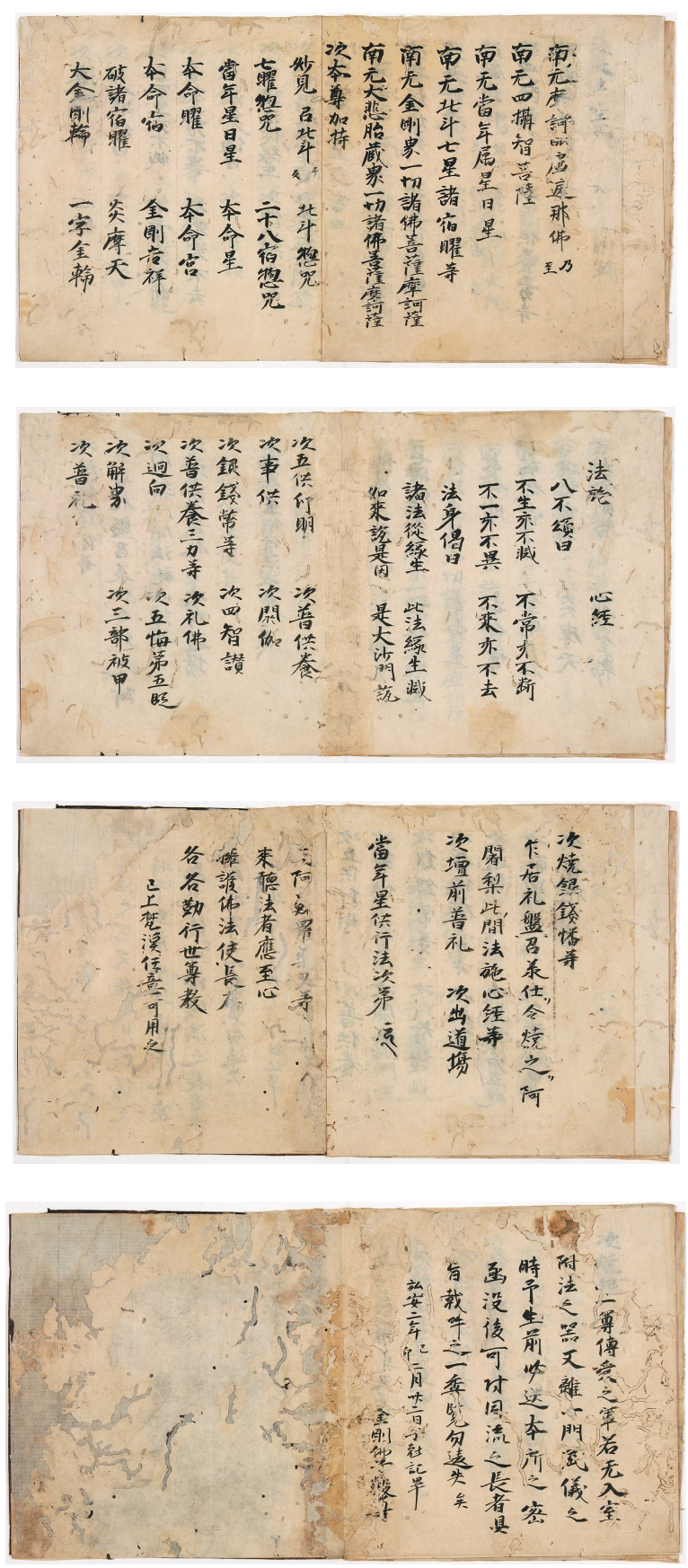

Culture and Cosmos 
140 Two Mediaeval Manuscripts on the Worship of the Stars from the Fujii Eikan Collection

\section{Kuȳ hireki 九曜秘暦 (The Secret Calendar of the Nine Luminaries), original manuscript, Fujii Eikan Archives, Art Research Centre, Ritsumeikan University, Kyoto.}

Fig. 1 The Sun

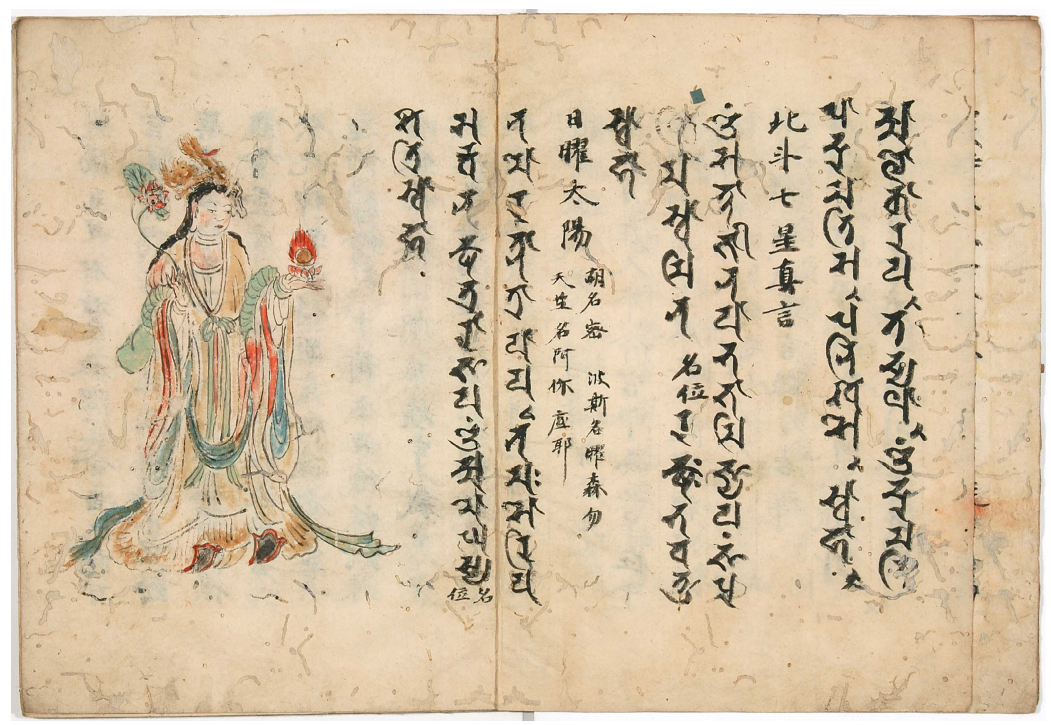

Fig. 2 The Moon

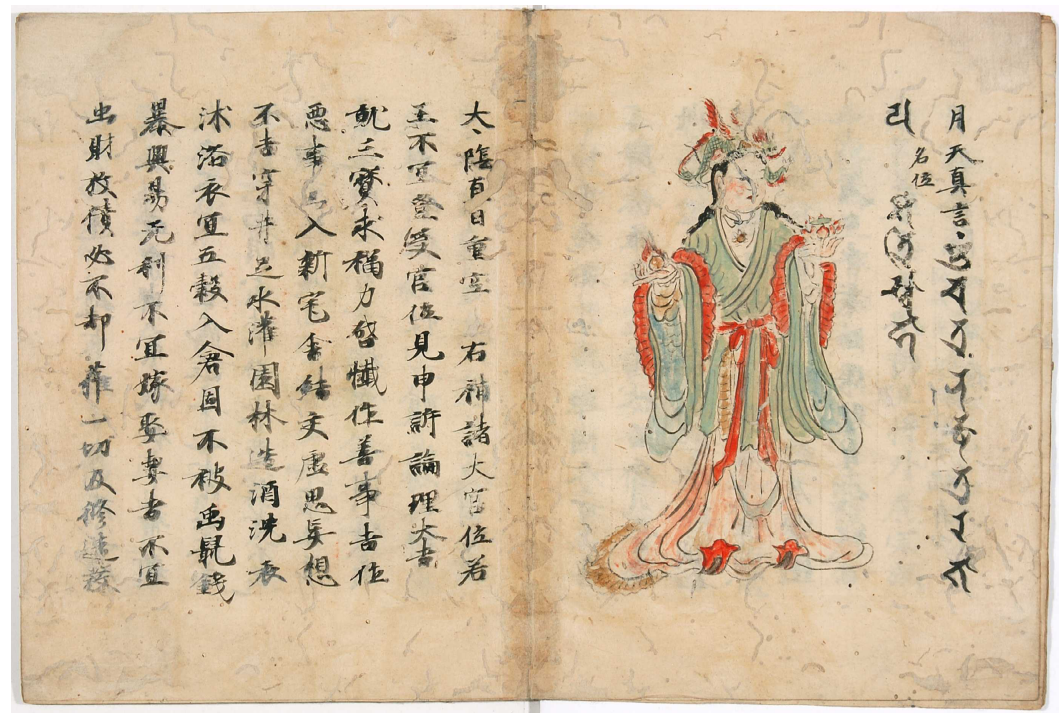

Culture and Cosmos 
Fig. 3 Mars

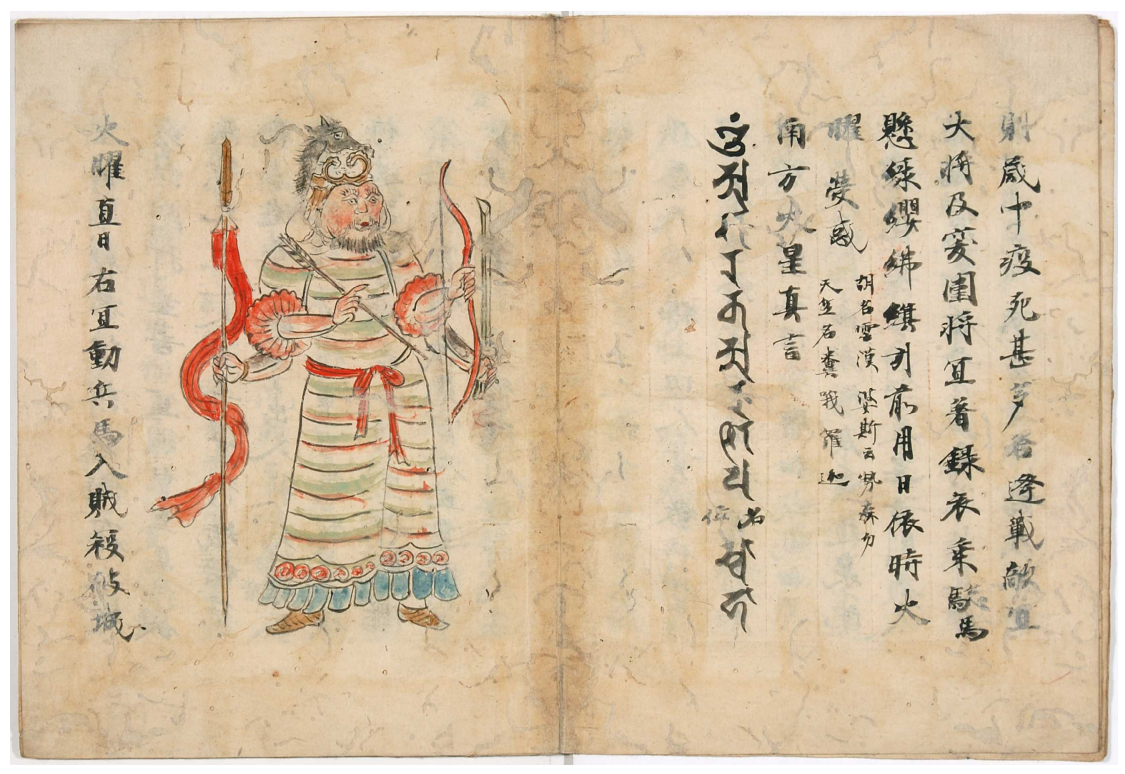

Fig. 4 Mercury

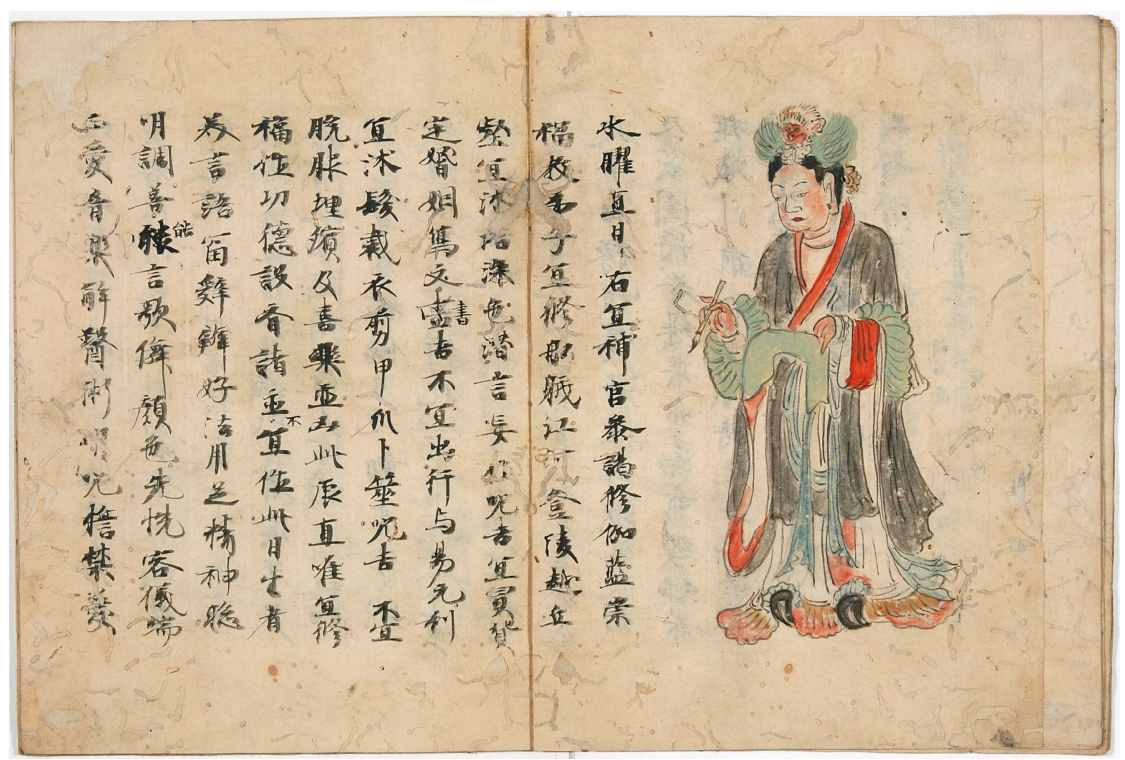

Culture and Cosmos 
142 Two Mediaeval Manuscripts on the Worship of the Stars from the Fujii Eikan Collection

Fig. 5 Jupiter

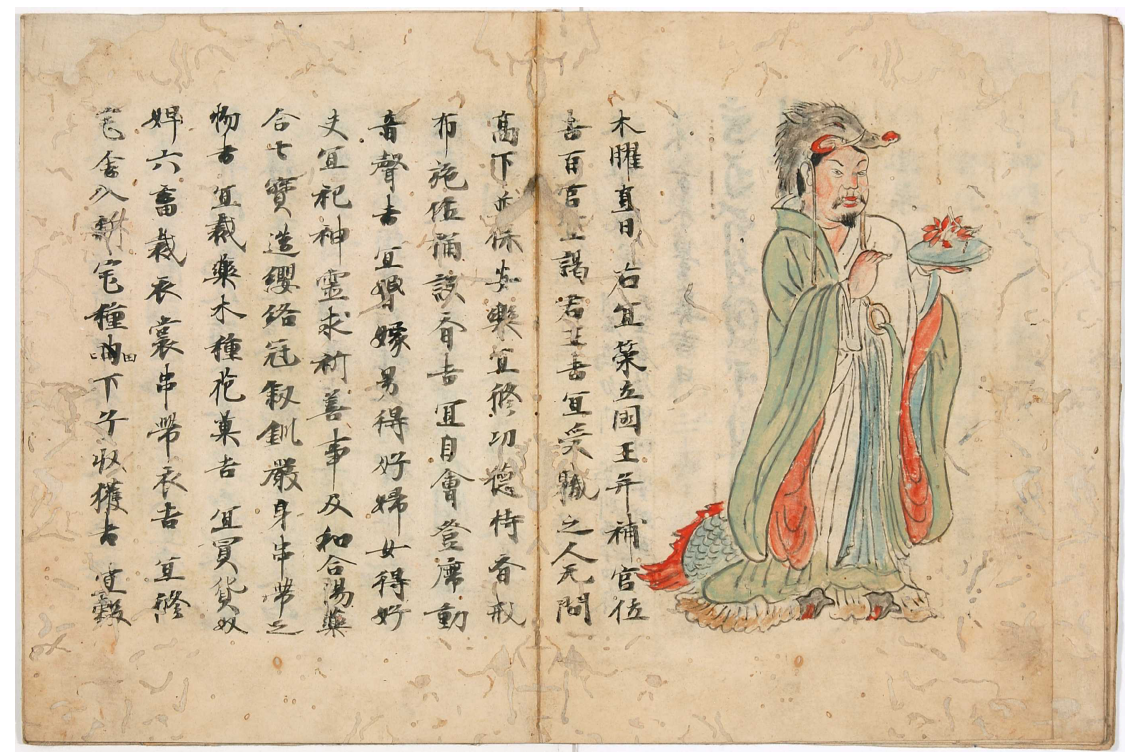

Fig. 6 Venus

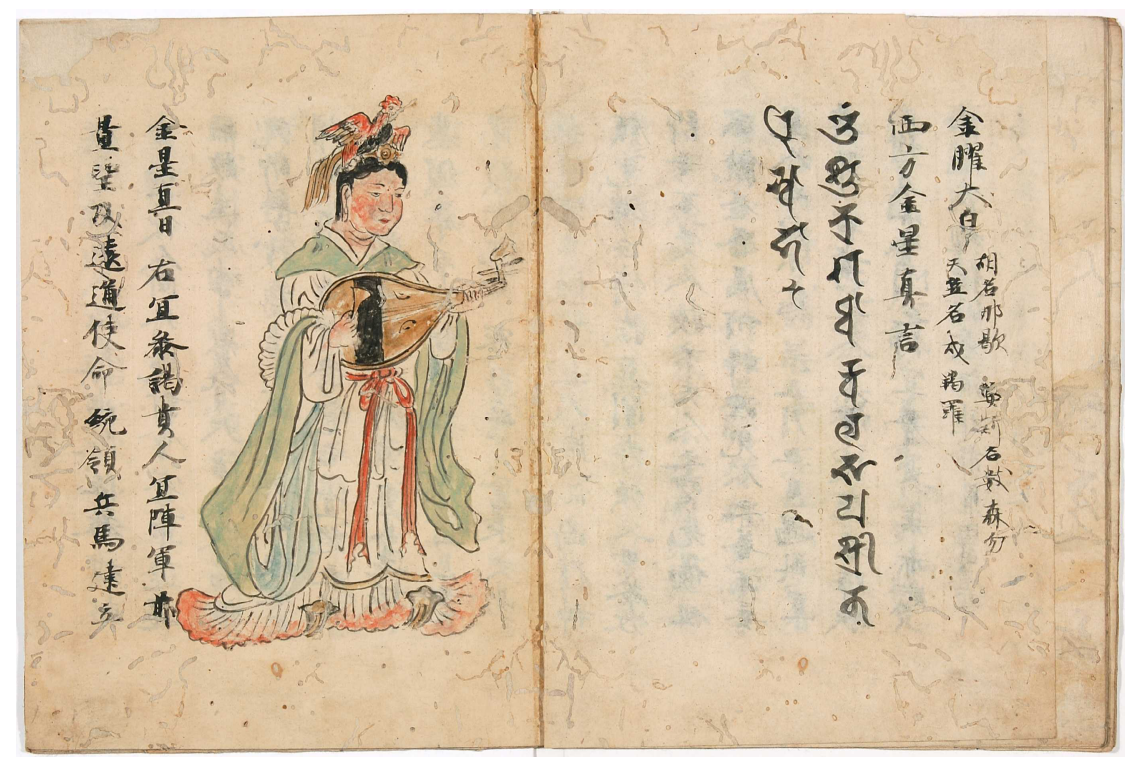

Culture and Cosmos 
Ikuyo Matsumoto 143

Fig. 7 Saturn

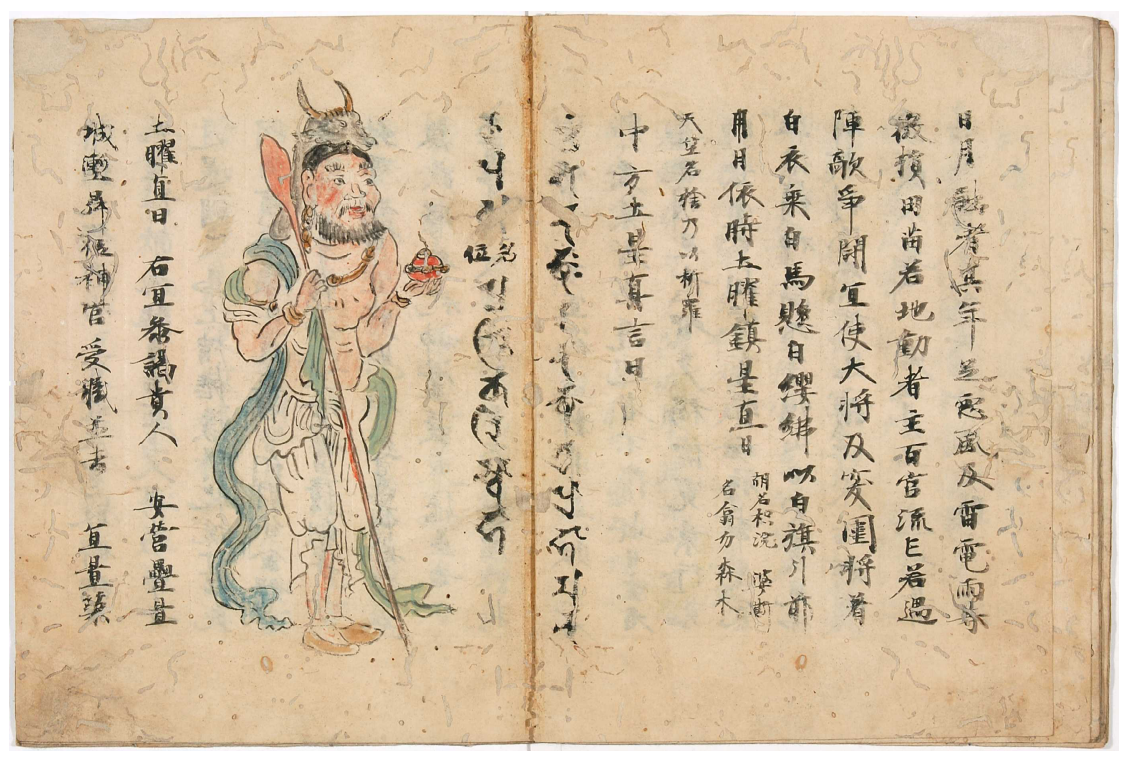

Fig. 8 Rāhu

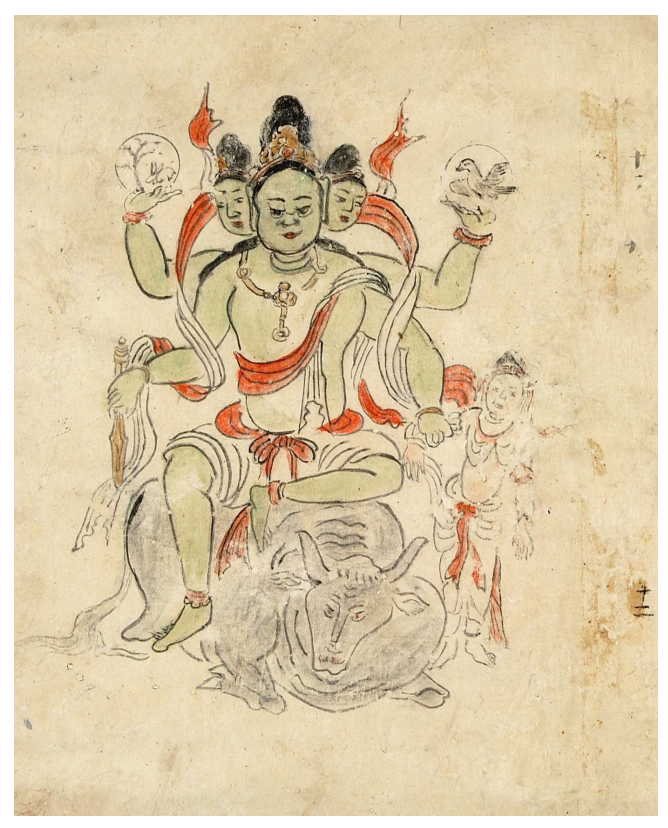

Culture and Cosmos 
144 Two Mediaeval Manuscripts on the Worship of the Stars from the Fujii Eikan Collection

Fig. 8a Rāhu's mantra, as included in the manuscript.

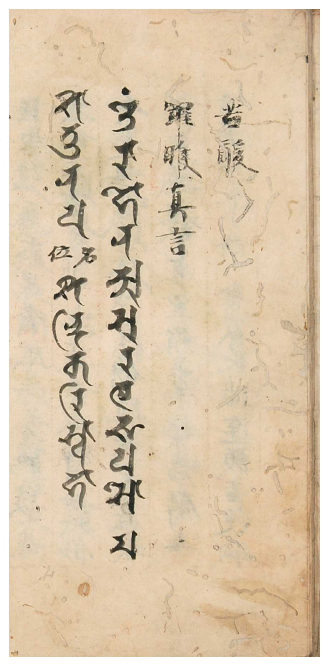

Fig. 9 Ketu

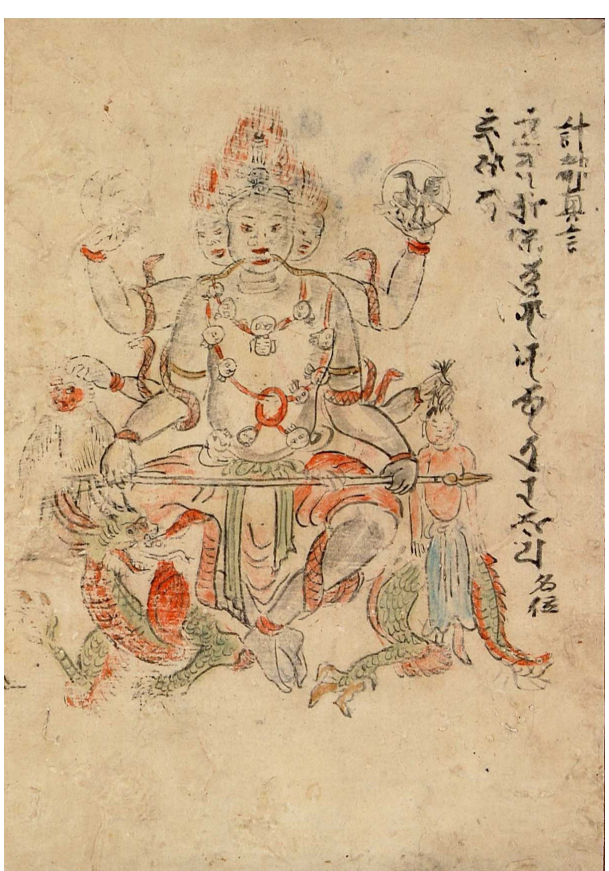

Culture and Cosmos 